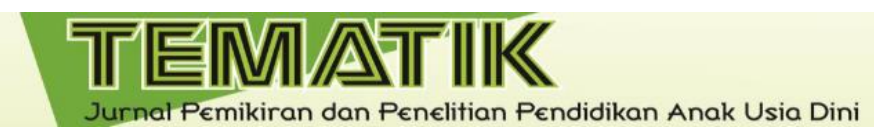

ISSN: 2476 - 9363

Volume 5 Nomor 1 Tahun 2019

\title{
PENGARUH PENGGUNAAN MEDIA KARTU ANGKATERHADAP KEMAMPUAN BERHITUNG PERMULAAN DI TAMAN KANAK- KANAK
}

\author{
Annisa Sevtiandini $\mathrm{A}^{1}$ \& Hajerah $^{2}$ \\ ${ }^{12}$ Pendidikan Guru Pendidikan Anak Usia Dini, Universitas Negeri Makassar
}

\begin{abstract}
:
This study examines the effect of using number card media on children's initial numeracy skills in group B at Paud Kartini, Bantaeng Regency before and after being given treatment in the form of using number card media. The type of research used is design control group design, the approach chosen is a quantitative approach. The subjects in this study were 22 children. The sampling technique used was random sampling technique. The results showed that there were differences in the early counting ability of children before and after the use of number card media on the beginning counting abilities of children in group B in Paud Kartini, Bantaeng Regency.
\end{abstract}

Keywords: Card media, counting.

\begin{abstract}
Abstrak:
Studi ini menelaah tentang Pengaruh Penggunaan Media Kartu Angka terhadap Kemampuan Berhitung Permulaan Anak Pada kelompok B di Paud Kartini Kabupaten Bantaeng sebelum dan sesudah diberikan perlakuan berupa penggunaan media kartu angka. Jenis penelitian yang digunakan adalah Design control group design, pendekatan yang dipilih iyalah pendekatan kuantitatif. Subyek dalam penelitian ini terdapat 22 anak. Tehnik pengambilan sampel yang digunakan yaitu tehnik random sampling. Hasil penelitian menunjukkan bahwa ada perbedaan kemampuan berhitung permulaan anak sebelum dan sesudah penggunaan media kartu angka terhadap kemampuan berhitung permulaan anak pada kelompok B di Paud kartini Kabupaten Bantaeng.
\end{abstract}

Kata Kunci: Media kartu, berhitung.

Artikel dengan akses terbuka dibawah licenci Creative Commons Attribution-NonCommercial 4.0 International License. (https:// creativecommons.org/licenses/by-nc/4.0/). Received: Mei 2019, Accepted: Mei 2019, Published: Juni 2019 


\section{PENDAHULUAN}

Pendidikan anak usia dini merupkan salah satu bentuk pendidikan yang berada pada jalur pendidikan formal. Pendidikan anak usia dini juga merupakan pendidikan yang diarahkan untuk mengembangkan seluruh ranah perkembangan anak, baik aspek nilai moral agama, fisik motorik, bahasa, kognitif maupun sosial emosional. Kelima aspek perkembangan ini harus dikembangkan dan ditingkatkan secara seimbang dan berkesinambungan karena pada dasarnya kelima aspek ini saling berhubungan satu sama lain. Sebagai lembaga pendidikan prasekolah, tugas utama seorang pendidik di Taman Kanak Kanak adalah mempersiapkan anak dengan memperkenalkan berbagai pengetahuan, sikap/perilaku, dan keterampilan agar anak dapat melanjutkan kegiatan belajar yang sesungguhnya di sekolah dasar. Salah satu bidang pengembangan dasar yang perlu dikembangkan sejak usia dini adalah perkembangan kognitif, salah satunya berupa kemampuan berhitung permulaan bagi anak usia dini. Kemampuan berhitung merupakan kemampuan dalam menggunakan penalaran, logika dan angka angka.

Depdiknas (2007:1) mengemukakan bahwa kegiatan atau permainan berhitung di TK tidak hanya terkait dengan kemampuan kognitif saja, tetapi juga kesiapan mental sosial dan emosional, karena itu dalam pelaksanaannya harus dilakukan secara menarik, bervariasi dan menyenangkan. Kegiatan berhitung merupakan bagian dari matematika yang diperlukan untuk menumbuh kembangkan keterampilan berhitung yang sangat diperlukan dalam kehidupan sehari hari, terutama konsep bilangan yang merupakan juga dasar bagi pengembangan kemampuan matematika maupun kesiapan untuk mengikuti pendidikan dasar. Karena pada dasarnya anak usia 5-6 tahun atau anak TK kelompok B hendaknya sudah mampu untuk menyebutkan angka bila diperlihatkan lambang bilangannya, dan menyebutkan jumlah benda dengan cara menghitung. Juga anak umur 5-6 tahun sudah dapat menyebutkan lambang bilangan 1-10, menggunakan lambang bilangan untuk menghitung, dan mencocokkan bilangan dengan lambang bilangan. Konsep bilangan menjadi sangat penting karena merupakan konsep matematika yang harus dikuasai oleh anak, karena akan menjadi dasar bagi penguasaan konsep matematika selanjutnya

Berdasarkan hasil observasi di PAUD Kartini Kabupaten Bantaeng terdapat beberapa anak pada kelompok B yang rata rata kemampuan berhitung permulaannya masih rendah, dengan kata lain, anak belum lancar atau belum mahir menyebutkan angka bila diperlihatkan lambang bilangannya dan menentukan angka bila diperlihatkan jumlah gambar (menjumlah/menghitung). Rendahnya kemampuan berhitung anak kelompok B disebabkan karena kurangnya minat anak didik untuk belajar berhitung dengan benda-benda yang ada dilingkungan, anak anak lebih menyukai pembelajaran mewarnai, motorik halus dan bermain di luar 
karena metode pembelajaran yang diterapkan guru bersifat membosankan, seperti mengerjakan Lembar kerja anak (LKA).

PAUD Kartini Kabupaten Bantaeng melaksanakan pembelajaran berhitung dengan benda-benda dengan menggunakan alat peraga yang sederhana. Para pendidik menggunakan media yang ada dalam lingkungan sekolah misalnya, pensil, buku, kapur, dan sebagainya. Hal ini membuat anak merasa bosan dan hal ini sangat mempengaruhi tingkat belajar, semangat dan kemampuan anak dalam pembelajaran berhitung. Ini dibuktikan dengan hasil pekerjaan anak pada tiap tengah semester. Dari 22 orang anak hanya ada beberapa anak yang sudah mampu berhitung dan sebagian lainnya masih perlu bimbingan guru, ternyata anak yang belum mampu berhitung belum dapat menggunakan media yaitu dengan menggunakan jari-jari tangan. Berdasarkan kenyataan tersebut, maka dalam kegiatan berhitung permulaan anak usia dini diperlukan model pembeljaran yang berpusat pada anak khususnya yang berorientasi pada peningkatan kemampuan berhitung permulaan melalui bermain kartu angka menjadi penting. Karena bermain kartu angka adalah salah satu cara untuk meningkatkan kemampuan berhitung permulaan anak. Dengan bermain kartu angka tersebut anak akan lebih banyak mengikuti pelajaran berhitung dengan gembira sehingga minatnya dalam kegiatan berhitung semakin besar dalam proses pembelajaran. Dengan demikian penggunaan kartu angka dalam proses belajar mengajar akan membantu guru mempermudah memahami angka demi angka yang terdapat pada kartu angka kepada anak didik di TK.

Di dalam persiapan menyusun model pembelajaran berhitung ini disesuaikan dengan karakteristik anak, perkembangan fisik dan psikologis anak TK, keadaan lingkungan sekitar dan ketersediaan sarana dan prasarana pendidikan sangat mendukung keberhasilan pembelajaran. Kegiatan berhitung ini untuk meningkatkan kemampuan dan kreativitas anak sesuai dengan tahap perkembangannya. Permainan berhitung merupakan bagian dari matematika, diperlukan untuk menumbuh kembangkan keterampilan berhitung yang sangat diperlukan dalam kehidupan sehari hari, terutama kemampuan berhitung yang merupakan dasar bagi kemampuan matematika maupun kesiapan untuk mengikuti pendidikan dasar.

\section{METODOLOGI}

Pendekatan penelitian ini adalah kuantitatif karena menggunakan statistik untuk menguji hipotesis. Penelitian ini bersifat eksperimen. Sugiyono (2017: 72) mengemukakan bahwa, "penelitian eksperimen adalah metode penelitian yang digunakan untuk mencari pengaruh perlakuan tertentu terhadap yang lain dalam kondisi yang terkendalikan". Masalah yang telah dianalisis oleh peneliti yaitu pengaruh penggunaan media kartu angka terhadap kemampuan berhitung prmulaan pada anak usia dini kelompok B di PAUD Kartini, Kab.Bantaeng. Jenis penelitian 
yang digunakan adalah Design Control Group Design. Peneliti memilih jenis penelitian Design Control Group Design karena peneliti ingin membandingkan tingkat kemampuan berhitung yang telah diberikan penanganan menggunakan media kartu angka dengan tingkat kemampuan berhitung siswa yang tidak diberikan penanganan dengan menggunakan media kartu angka pada kelompok penelitian.

Dalam kegiatan pengembangan kemampuan berhitung permulaan, penelitian dilakukan 2 kali yaitu sebelum perlakuan dan sesudah perlakuan pada masingmasing kelompok penelitian. Penelitian yang dilakukan sebelum perlakuan disebut pre tes, yaitu melakukan non tes berupa penelitian terhadap anak usia dini. Untuk mengetahui kemampuan berhitung permulaan sebelum diberikan perlakuan melalui penggunaan media kartu angka. Sedangkan penelitian sesudah perlakuan disebut pos tes, yaitu melakukan non tes berupa penelitian terhadap anak. Untuk mengetahui kemampuan berhitung permulaan sesudah diberikan perlakuan melalui penggunaan media kartu angka. Perbedaan hasil diasumsikan sebagai efek dari perlakuan yang telah diberikan, sehingga dapat menunjukkan apakah ada pengaruh penggunaan media kartu angka terhadap kemampuan berhitung permulaan pada anak.

\section{HASIL DAN PEMBAHASAN}

Berdasarkan hasil analisis uji Wilcoxon menunjukkan terdapat perbedaan yang signifikan antar kemampuan berhitung permulaan anak kelompok control dan anak kelompok eksperimen. Perbedaan yang dimaksud adalah rata-rata nilai kemampuan berhitung permulaan anak mengalami peningkatan setelah menggunakan media kartu angka dibandingkan nilai kemampuan berhitung permulaan anak yang tidak diberi perlakuan berupa penggunaan media kartu angka.

Hal ini disebabkan karena penggunaan media kartu angka mengajak anak untuk mengenal dan mengetahui berbagai macam angka, bentuk angka, dan ukuran permainan yang diberikan serta melatih kemampuan berhitung permulaan anak yaitu dengan melakukan kegiatan berhitung bersama, mengenal angka dan bentuknya, juga pada saat anak diajak dalam sesi tanya jawab mengenai kartu angka yang diperlihatkan. Hal ini berarti, dalam penggunaan media kartu angka anak dilatih secara langsung untuk mengembangkan kemampuan berhitung permulaan.

Pemberian perlakuan berupa penggunaan media kartu angka dilakukan sebanyak 3 kali, pertemuan dilakukan selama 2 minggu dalam pelaksanaan penelitian. Pada pertemuan pertama peneliti melakukan pretest dan pemberian perlakuan pada pertemuan kedua dan terakhir peneliti melakukan posttest. Penerapan penggunaan media kartu angka disesuaikan dengan tema pembelajaran, yaitu tema alam semesta dengan subtema benda-benda dilangit. Hasil penelitian berdasarkan analisis deskriftif pada populasi yang digunakan, dengan jumlah 22 orang anak, menunjukkan bahwa sebelum perlakuan berupa penggunaan media 
kartu angka, rata-rata anak belum mampu menjawab pertanyaan hal ini dapat dilihat bahwa kemampuan berhitung permulaan anak masih rendah. Selanjutnya setelah melakukan tes pretest, diterapkan perlakuan berupa penggunaan media kartu angka.

Selanjutnya, hasil penelitian berdasarkan analisis deskriptif setelah perlakuan berupa penggunaan media kartu angka untuk mengetahui tingkat kemampuan berhitung permulaan anak, sudah berkembang sesuai harapan atau termasuk dalam kategori Baik. Pada tahap ini anak didik cenderung aktif dan antusias, rata rata anak didik sudah mampu mengenal urutan benda dari yang terkecil sampai yang terbesar, Anak dapat mengelompokkan benda sesuai dengan ukurannya, Anak dapat mengenal lambang bilangan dengan cara menyebutkan 1-20, Anak dapat menunjuk kartu angka sesuai dengan jumlah benda yang ada dihadapannya, Anak dapat memasangkan/ mencocokkan lambang bilangan dengan jumlah benda yang ada (120).

Hal tersebut sesuai dengan pembahasan sebelumnya bahwa pengalaman belajar agar anak dapat menguasai kemapuan kognitif dengan lebih baik. Disamping itu kartu angka digunakan dengan tujuan mengajarkan suatu proses atau prosedur, mengkonkritkan, dan mengembangkan kemampuan kognitif anak. Dalam depdikbud (Selfiani,2012) pengertian kartu angka adalah kartu yang digunakan untuk mengetahui suatu angka dan benda. Karena media kartu angka ini merupakan media visual jadi media kartu angka ini dapat merangsang kecerdasan dan ingatan anak dalam memahami lambang bilangan. Sesuai dengan teori Piaget yang mengatakan bahwa anak pada usia 2-7 tahun berada pada tahap praoperasional, sehingga anak belajar memahami konsep dari gambar-gambar atau benda yang ada disekitarnya (Dhieni,2007:2.15). melalui media kartu angka ini, anak lebih mudah dalam mengenal, mengetahui dan mengingat lambang bilangan.

Adapun konsep berhitung permulaan yang perlu diterapkan dalam proses pembelajaran berhitung permulaan yaitu menurut Depdiknas (2000:9) pada anak usia prasekolah matematika hanya pengalaman dan bukan penguasaan. Dari penjabaran tersebut, dapat disimpulkan bahwa konsep berhitung permulaan untuk anak usia dini dapat diperkenalkan dengan urutan pembelajaran sebagai berikut, yaitu: korespondensi satu-satu atau membilang dari tingkatan yang sangat sederhana, pola, mengklasifikasikan, membilang atau menghafal bilangan, makna angka dan pengenalannya, bentuk, ukuran ( berat,isi,panjang), waktu dan ruang, dan penambahan dan pengurangan. Dalam penelitian ini, adapun kegiatan yang diberikan dijelaskan dalam scenario pembelajaran yang telah dibuat. Kegiatan tersebut antara lain pertama tama guru menjelaskan tentang permainan yang akan diberikan beserta cara memainkannya. Selanjutnya peneliti menyiapkan alat serta bahan berupa media kartu angka, media gambar bulan, bintang dan matahari. Setelah itu permainan pertama anak mencari angka yang sesuai dengan jumlah 
gambar bulan yang telah dipajang didepan kelas, kemudian anak berlomba untuk menempel kartu angka tersebut disebelah gambar bulan.

Peran guru dalam kegiatan ini adalah mengarahkan anak didik dalam berhitung dan memasangkan angka yang benar pada gambar bulan yang ada didepan kelas. Selain itu guru memberikan pertanyaan mengenai angka 1-20,bentuk dan ukuran media gambar, kemudian guru meminta anak menunjukkan kartu angka sesuai angka yang disebutkan oleh guru. Pada saat penggunaan media kartu angka anak tidak hanya menjadi pembelajar yang pasif tapi juga aktif, hal ini dapat dilihat pada saat kegiatan dilaksanakan, anak sangat antusias dalam menjawab pertanyaan guru, mencari angka yang bersangkutan dan berlomba menempelkan kartu angka pada gambar didepan kelas. Hal hal yang perlu diperhatikan dalam penggunaan media kartu angka adalah ketersediaan media yang diperlukan seperti kartu angka, dan media bergambar yang dapat menarik perhatian anak.

Penjelasan diatas semakin mendukung pernyataan Depdiknas (2000: 8) mengemukakan prinsip-prinsip dalam menerapkan permainan berhitung di Taman Kanak Kanak yaitu, permainan berhitung diberikan secara bertahap, diawali dengan menghitung benda-benda atau pengalaman peristiwa konkrit yang dialami melalui pengamatan terhadap alam sekitar dan melalui tingkat kesukarannya, misalnya dari konkrit ke abstrak, mudah kesukar, dan dari sederhana ke yang lebih kompleks. Permainan berhitung akan berhasil jika anak diberi kesempatan berpartisipasi dan dirangsang untuk menyelesaikan masalah-masalahnya sendiri, permainan berhitung membutuhkan suasana menyenangkan dan memberikan rasa aman serta kebebasan bagi anak. Untuk itu diperlukan alat peraga/media yang sesuai dengan benda sebenarnya (tiruan), menarik dan bervariasi, mudah digunakan dan tidak membahayakan. Selain itu bahasa yang digunakan didalam pengenalan konsep berhitung seyogyanya bahasa yang sederhana dan jika memungkinkan mengambil contoh yang terdapat lingkungan sekitar.

Tidak berbeda jauh dengan pendapat dari Yew (Susanto, 2011:103) yang mengungkapkan beberapa prinsip mengajarkan berhitung pada anak, diantaranya;

Membuat pelajaran yang menyenangkan, mengajak anak terlibat secara langsung, membangun keinginan dan kepercayaan diri dalam menyesuaikan berhitung, hargai kesalahan anak dan jangan menghukumnya, fokus pada apa yang anak capai. Pelajaran yang mengasyikkan dengan melakukan aktivitas yang menghubungkan kegiatan berhitung dengan kehidupan sehari hari.

Sesuai dengan keterkaitan teori tersebut dan berdasarkan hasil penelitian yang dilakukan, dapat diketahui bahwa penggunaan media kartu angka merupakan stimulasi yang tepat bagi kemampuan berhitung permulaan anak. Oleh sebab itu pendidik seharusnya lebih sering menerapkan pembelajaran dengan media yang lebih kompleks dalam mengembangkan aspek aspek perkembangan anak. 


\section{KESIMPULAN}

Berdasarkan hasil analisis dan uji statistik pada pembahasan sebelumnya, maka dapat ditarik kesimpulan bahwa dengan menerapkan penggunaan media kartu angka dapat meningkatkan kemampuan berhitung permulaan anak kelompok B pada Paud Kartini Kabupaten Bantaeng. Peningkatan hasil tes setelah perlakuan disebabkan oleh penggunaan media yang menarik dan dapat meningkatkan minat belajar anak dalam hal aktivitas pembelajaran berhitung. Salah satu media tersebut adalah kartu kata sebagai media belajar yang dapat mengarahkan pencapaian kompetensi berhitung anak.

\section{DAFTAR PUSTAKA}

Arikunto, S. 2006. Prosedur Penelitian. Suatu Pendekatan Praktek. Jakarta: Rineka Cipta

Alwi, 2005. Kamus Besar Bahasa Indonesia. Jakarta: Balai Pustaka

Depdiknas. 2007. Pedoman Pembelajaran Berhitung Permulaan Di Taman KanakKanak. Jakarta: Direktorat Jenderal Manajemen Pendidikan Dasar Dan Menengah Direktorat Pembnaan Taman Kanak-Kanak Dan Sekolah Dasar

Depdiknas. 2000. Permainan Berhitung di Taman Kanak-kanak. Jakarta: Ditrektorat Jenderal Pendidikan Dasar dan Menengah DirektoratJenderal Pendidikan Dasar dan Menengah Baian Proyek Peningkatan Mutu di Taman Kanak-kanak

Hurlock, E.B, 1999. Perkembangan Anak Julid I (edisi 6). Penerbit Erlangga : Jakarta

Jubaedah, 2010. Penerapan Bermain Edukatif Untuk Meningkatkan Kemampuan Berhitung. Malang

Mariani, D. (2018). Pengaruh Media Kartu Gambar Angka Terhadap Kemampuan Operasi Hitung Penjumlahan Pada Anak Di Raudhatul Atfhal Al-Kamal Jln Tegal Sari Lau Dendang Tahun Ajaran 2017/2018 (Doctoral dissertation, Universitas Islam Negeri Sumatea Utara Medan).

Mufarizuddin, M. (2017). Peningkatan Kecerdasaan Logika Matematika anak melalui bermain kartu angka kelompok $b$ di tk pembina bangkinang kota. Jurnal Obsesi: Jurnal Pendidikan Anak Usia Dini, 1(1), 62-71.

Musi, M. A. (2016). Peningkatan Keterampilan Berhitung Anak Usia Taman Kanak-Kanak Melalui Demonstrasi Dengan Media Gambar. Indonesian Journal of Educational Studies, 19(1).

Novitasari, R. (2016). Pengaruh Media Buah Angka Terhadap Kemampuan Kognitif Mengenal Lambang Bilangan 1-10 Kelompok A. PAUD Teratai, 5(3).

Patintingan, M. L. 2013. Penerapan Matode Jarimatika di TK Asoka Makassar. Tesis. Makassar. UniversitasNegeri Makassar 
Permendiknas. 2014. Permendikbud Nomor 146 tentang kurikulum 2013 Pendidikan Anak Usia Dini. Jakarta: Kemendikbud.

Wulandari, P. D., Wirya, N., Tirtayani, L. A., \& Psi, S. (2014). Penerapan Numbered Head Together Berbantuan Media Kartu Angka untuk Meningkatkan Kemampuan Mengenal Lambang Bilangan. Jurnal Pendidikan Anak Usia Dini Undiksha, 2(1). 